International Journal of Engineering \& Technology, $7(3.30)(2018) 259-261$
International Journal of Engineering \& Technology
WPC
Website www.sciencepubco.com/index.php/IJET
Research paper

\title{
Internal Communication Role in Improving Performance of Employees Hotel: Descriptive Study at Employees Sari Ater Hotel \& Resort in Ciater, Subang Regency, West Java Province
}

\author{
Poppy Ruliana $^{1^{*}}$, Susi Andrini ${ }^{1}$, Puji Lestari ${ }^{2}$, Yasinta Indrianti ${ }^{3,4}$, Sasmoko $^{4}$ \\ ${ }^{1}$ Communication, STIKOM Interstudi, Indonesia \\ ${ }^{2}$ Department of Communication Science, Faculty of Social and Political Science, Universitas Pembangunan Nasional Veteran \\ Yogyakarta, Indonesia \\ ${ }^{3}$ Research Interest Group for Educational Technology, Bina Nusantara University \\ ${ }^{4}$ Primary Teacher Education Department, Faculty of Humanities, Bina Nusantara University, Indonesia \\ *Corresponding author E-mail: poppyruliana30@gmail.com
}

\begin{abstract}
Communication problems are one of the most important for every organization because it is a tool that binds all management functions within the organization. The effectiveness of internal communication at Sari Ater Hotel \& Resort is very central to the survival of an organization and the performance organizaton's of a hotel that can be seen from the communication hierarchy in vertical, diagional and horizontal communication. The concept of internal communication refers to the opinions of Ronald Adler and George Rodman, who argued that in the process of internal communication occurs through vertical communication process, horizontal communication and diagonal communication. The method used in this research is sirvey with descriptive research type with quantitative approach. This method is suitable because it only provides an overview of research related to the role of internal communication effectiveness in improving employee performance Sari Ater Hotel \& Resort. The purpose of this study is to know and analyze the performance of employees of Sari Ater Hotel \& Resort. The results show that the vertical and horizontal communication dimensions in internal organizational communication play a role and effective in improving employee performance Sari Ater Hotel \& Resort
\end{abstract}

Keywords: Interal Communication, Performance.

\section{Introduction}

Organizational communication activities of a hotel, there is interaction in the field of work between departments and the existence of interdependence among employees through communication, because only with communication influence on the behavior of individuals or employees can occur. The interaction is not only internal, but also how to communicate with the external public, for example, building relationships with government or consumers.

Internal communication can be seen as an opportunity to attract employees and give them a reason to promote the organization. By engaging employees in the vision of the organization, giving them proper qualifications or messages, educating them about the brand and direction of the organization better and providing evidence for the message, their level of satisfaction increases.

Internal communication should encourage employees to take a personal approach and apply creativity while promoting vision. Also in terms of planning, implementation and measurement, internal communication must integrate focus and direction. Studying, doing, measuring, and introducing feedback to employees - if done well - is important to build on their performance.

This research discusses the problem of internal communication effective and performance of hotel employees, and aims to analyze the relationship between the two, in the case of Sari Ater Hotel \& Resort located in Ciater, Subang Regency, West Java.

\section{Literature Review}

\subsection{Understanding the Hotel.}

Hotels according to the American Hotel and Motel Association (AHMA) as quoted by Steadmon and Kasavana are "a hotel may be defined as an establishment whose primary business is providing lodging facilities for the general public and which furnishes one or more of the following services: food and beverage service, room attendant service, uniformed service, Laundering of linens and use of furniture and fixtures".

\subsection{Internal Communication}

Internal communication is a fundamental part of all work interactions within an organization that coordinates, motivates and empowers employees and therefore directly affects the productivity of the company. The full understanding of employees about the goals of organizational communication and the recognition of their own responsibilities that ensures an effective communication flow creates an informed and committed workforce that ultimately results in better outcomes $[1,6]$. Over the years of study into the subject, the realization of communication significance has been embedded in the company. Communication discipline has changed 
from additional to mandatory and has proclaimed "the life-blood of the organization" [2]

Van Riel and Fombrun explain that communication now constitutes of five key components. They are structure, flow, specific inputs, climateand culture. This may guide the internal communication process more systematically. Lawrence D. Brennan defines internal communication as: interchange of ideas between administrators and as certain structure (organization) and interchange of ideas horizontally and vertically within the firm which gets work done (operation and management). Krone in Van Riel and Fomburn concluded that the main idea of employee relations consists of four unique roles such as efficiency, shared meaning, connectivity and satisfaction.

In addition, information does not flow literally. In fact, the information itself does not move, which is actually visible is the delivery of a message, interpretation penyampain it, and the creation of other delivery. The creation, delivery and interpretation of messages is a process that distributes messages throughout the organization through the direction of top-down and bottom-up information known as vertical communication. Then the direction of the flow of information within the organizational structure flows between parts or divisions where there is interaction through vertical communication, horizontal communication Next information flows to the other different parts known as diagonal communication [3].

\subsection{Employee Performance}

Gilbert argues, that performance is basically a product of time and opportunity. "The opportunity without time to pursue the opportunity is nothing. And the time we do not have, which gives no chance, even has less value. In the context of the vitality of work within an organization, Gilbert's views on performance are consistent with what we consider important to empower workers. To work competently, workers make high-value achievements for the organization while reducing costs to achieve goals. Gilbert explains that a lot of energy or work, coupled with a lot of knowledge, and applied with high enthusiasm, with no comparable achievement, describes improper performance. (in Pace and Faules [4]

\section{Methodology}

The method used in this research is sirvey with descriptive research type and quantitative approach. This method is suitable because it only provides an overview of research relating to the role of internal communication effectiveness in improving employee performance Sari Ater Hotel \& Resort, using a variety of concepts, theories and approaches in accordance with the problems and objectives of research.

The purpose of this effective internal communication research is to analyze the relationship or interrelationship between the two, in the case of Sari Ater Hotel \& Resort located in Ciater, Subang Regency, West Java. In addition to providing some guidance on effective internal communication situations so as to predict whether an effective internal communication dimension can improve employee performance or not so that there can be a good change in organization at Sari Ater Hotel \& Resort because all organizations, regardless of size or object activities, should listen to them as the other person and, at the same time, fulfill public expectations characterized by diversity and urgency.

Internal communication practices are effectively linked to the ongoing internal communication process by looking at communication methods and communication techniques applied so that it is expected to take advantage of possible approaches to diagnose so that internal communication is more effective and practical in improving employee performance at Sari Ater Hotel \& Resort

\section{Research Findings and Arguments}

Communication is the liaison between the organization's need for a change and the employee's need for security. Internal communication at Sari Ater Hotel \& Resort occurs through the process of information flow submitted by the leadership to subordinates (downward communication), or vice versa where employees can give suggestions to the leader (upward communication) and can also flow information is delivered in the context between departments with other departments so that there is open communication in the management level (Horizontal Commucation) and can cross-departmental communication (diagonal / lateral communication). So it can be said that the theory put forward by Ronald Adler and George Rodman in accordance with the internal communication situation that occurred at Sari Ater Hotel \& Resort. To function effectively within an organization, managers must also be able to communicate effectively through horizontal communications as well as vertical communications that have different effects or effects when a manager or employee makes a communication to a superior or subordinate or between departments through coordination between them, as shown in the picture below

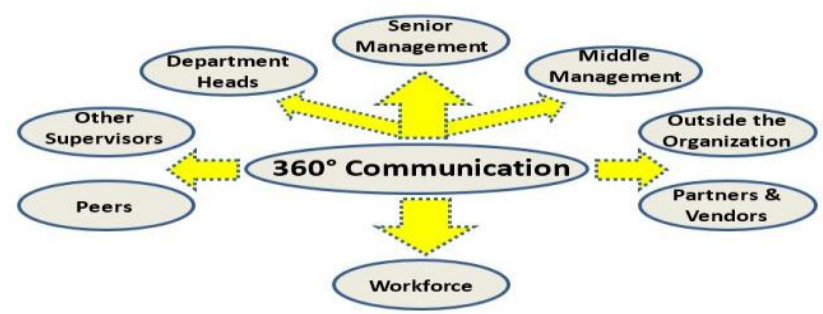

The picture above illustrates that the management and employees of Sari Ater Hotel \& Resort spend more than three quarters of their time in some form of interpersonal communication situation. Poor communication skills carry a lot of responsibility. Employees and especially managers who do not communicate effectively are at a disadvantage and do not thrive in the organization. Even though we have communicated with others, the process of transmitting information from one person to another is complex. Research has found that there is erosion of meaning in the environment of 40-60 percent in the transmission of information from one person to another. The level of effectiveness of internal communication has been done by the Director of Operations Sari Ater Hotel \& Resort Sari Ater Hotel \& Resort among others through activities:

a. Board of Directors meetings for top management level

b. Meeting of Shareholders (Commissioners)

c. Morning Briefing where the top level of management and level of madia is the managers involved

d. in the group communication discussion forum which is the hearing of all divisions / departments on

e. the activities that have been done.

f. Meeting each division / department in the company's operational activities,

g. MOD is a personal duty at night to monitor or monitor Sari Ater Hotel \& Resort activities

h. and other formal internal activities

Internal communication above is important to do because it can open a wider communication space so that the flow of information related to the work program can be communicated well and effectively to all personnel involved in accordance with the management system used by the company an internal communication strategy designed and run with both will motivate employees in improving performance. It is the company's policy that will build the team, build pride in working and encourage people to work harder to face the competition in order to get the goal Sari Ater 
Hotel \& Resort will achieve. In addition, informal internal communication activities conducted by the management Sari Ater Hotel \& Resort is a family gathering involving family employees. This activity is important because the employee's family is a part that can be said is important because the employee's family is kepangtanganan company that can maintain the image or reputation of the company in the eyes of the audience.

\subsection{Employee Performance of Sari Ater:}

From the results of research indicate that to improve employee performance, human resource manager has made a guidance criteria of job performance appraisal or performance of permanent employee or contract employee purpose to see and evaluate everything related to job, position, or role in organization as work achievement or job performance in accordance with their respective responsibilities. Form of Employee Performance Appraisal (Employee Performance Appraisal Form) with aspects of the assessment as follows:
a. Work discipline
b. Appearance
c. Attitude and Behavior
d. Work process
e. Ability to work
f. Work result

The assessment is objectively and professionally assessed without any intervention from anyone and the results of this assessment are then evaluated and discussed at top management whether capable, incapable or incapable of performing the work or tasks assigned in accordance with their competencies. Competencies held by employees include:

a. Skill

\section{b. Knowledge \\ c. Behavior}

From the results of the evaluation the HR Manager or HRM Sari Ater reported to the Director of Operations and Head of Department and decided the results as follows:

a. Employees who perform far above what the company expects

b. employees who perform according to company expectations

c. employees who perform below the company's expectations

d. employees who perform far below corporate expectations

The criteria of employee performance appraisal at Sari Ater Hotel \& Resort applied are of course determined by several factors, namely ability (ability) can be seen from the competence (IQ), the ability of reality (knowledge and skill) and motivation (motivations) is formed by attitude ( attitude) in the face of all situations (situation) work. Another factor is the communication that can be a liaison or adhesive in interacting with fellow employees Sari Ater Hotel \& Resort.

Based on the above discussion, it can be said that the internal communication flow that terjadal in Sari Ater Hotel \& Resort, the process of achieving the message flowing in an organizational structure that reflects the hierarchy of communication and coordination between various elements or elements that interact with each other and have the function and responsibility answer directly to the President Director and Operational Director sari ater Hotel \& resort in a vertical communication that can be done with upward communication and downward commm and horizontal communication or communication parallel to coordinate each other The nature of this communication contextual, can be reciprocal (feed back) so that it can get information thoroughly, even though sometimes one way (one way communication) .The description of this tiered communication process as follows:

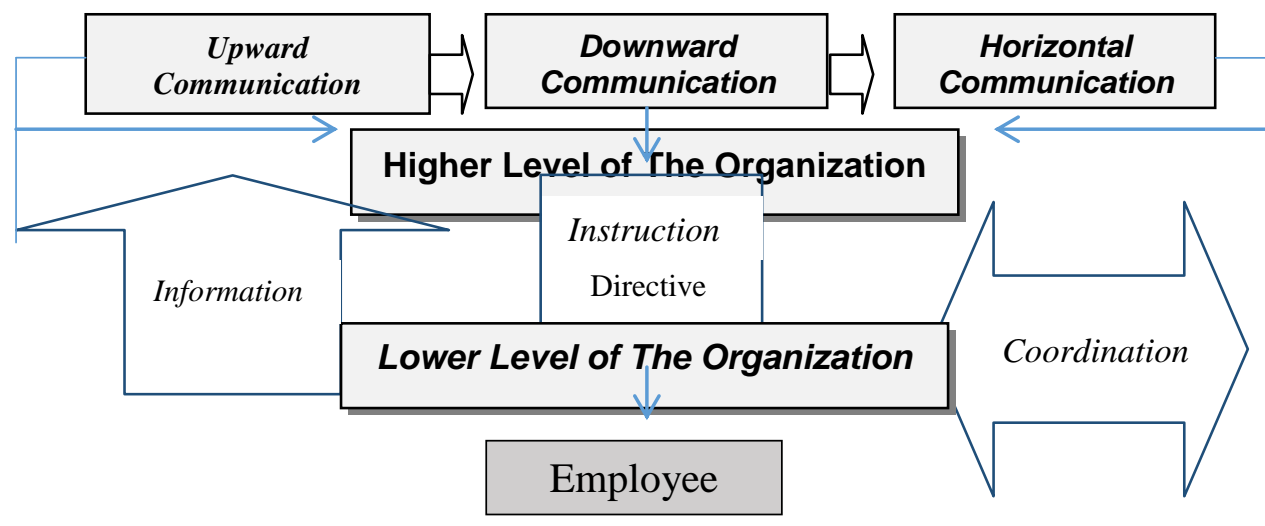

\section{Conclusion}

Based on the results of research and discussion that has been described, it can be drawn a conclusion in the process of organizational communication at Sari Ater Hotel \& Resort illustrates that the communication that occurs in Sari Ater Hotel \& Resort is vertical communication that the nature of downward communication and upward communication tend to be formal horizontal communication is more interpersonal nature associated with work in a professional manner so as to build work performance and diagonal communication tend to be informal. So internal communication plays an important role in improving employee performance Sari Ater Hotel \& Resort. The findings in this study, dominant interpersonal communication is done in the context of vertical communication.

\section{References}

[1] Ragusa A (2010), Internal Communication Management - Individual and Organizational

[2] Goldhaber (1995), Organizational Communication 6th Ed. USA: McGraw-Hill.

[3] Ronald Adler dan George Rodman (1997), Understanding Human Communication.

[4] Pace R, Wayne, Faulers \& Don F (1994), Organizational Communication 3rd Ed. New Jersey: Prentice-Hall, Inc.

[5] Gherghi I \& Gherghi D (2006), Comunicarea ORGANISASI ional i managementul situaiilorde criz, Ed.Ministerului Administration IEI i Internelor.

[6] Tahir, L., Mohd Said, M.N.H., Daud, K., Vazhathodi., S.H., \& Khan, A. (2016). The Benefits of Headship Mentoring: An Analysis of Malaysian Novice Head teachers' Perceptions. Educational Management Administration \& Leadership, 44, 420-450 